\title{
Jogi kultúra vagy társadalmi jogtudat?
}

\section{H. SZILÁGYI ISTVÁN ${ }^{1}$}

A jelen tanulmány célja a jogi kultúra és a társadalmi szintü jogtudat fogalmi relációinak elemzése. A gondolatmenet első részében áttekintést ad arról, hogy a jogi kultúra koncepciója hogyan jelent meg a hazai jogtörténet, öszszehasonlitó jogtudomány és a jogszociológia - közelebbröl a jogtudatkutatások - terén. A jogi antropológiai vizsgálódások során kidolgozott „kultúra” mint törzsfogalom és a „jog" szociológiai fogalmának mint differentia specifica felvázolását követöen tér rá a jogi kultúra fogalmának meghatározására. A koncepció jobb megvilágítása érdekében példaként a „professzionális jogi kultúra” egy sajátos szeletének, az ügyvédség hivatási önképének egy nemrégiben végzett empirikus kutatása során készitett elemzését ismerteti.

Észlelve a fogalomalkotás inkonzisztenciáit és bizonyos hiányosságait, az eszmefuttatás utolsó részében visszatér annak kezdöpontjához, és kritikai vizsgálat alá veti a jogi kultúra vázolt koncepcióját. Ehhez a Lawrence Friedman által vázolt koncepció körül a nemzetközi irodalomban kialakult vita áttekintését veszi alapul. Az elemzés eredményeként az a következtetés adódik, hogy a társadalmi jogtudat fogalmát „visszavegyük”, s azt a jogi kultúra fogalmával összekapcsolva újraértelmezzük, elszakitva azt az eredeti marxista, neomarxista hagyománytól, amelyben eredetileg gyökerezett.

Kulcsszavak: jogi kultúra, szociológiai jogfogalom, professzionális jogi kultúra, társadalmi szintü jogtudat

\section{Legal Culture or Social Legal Consciousness?}

The aim of this study is to analyse the conceptual relations of legal culture and social legal consciousness. The first section surveys the appearance of the notion of legal culture on the horizon of the Hungarian legal history, comparative law and legal sociology. The second introduces a working definition of legal culture using a general concept of 'culture, based on cultural anthropological findings, and a sociologically founded concept of 'law' as a differentia specifica. For a demonstration of the idea, the study presents a conceptual analysis of the Hungarian attorneys' professional selfimage used in a recent empirical study.

1 Egyetemi tanár, Pázmány Péter Katolikus Egyetem Jog- és Államtudományi Kar, e-mail: h.szilagyi.istvan@jak.pkke.hu 
Recognising the inconsistencies and shortcomings of the conceptualisation, the train of thoughts returns back to its starting point for a critical revision of the earlier outlined concept of legal culture in the last part. The survey of the scientific debate surrounding Lawrence Friedman's concept grounds the conclusion that we have to 'retrieve' the concept of social legal consciousness and re-interpret it in relation to the notion of legal culture, tearing it out from the neo-Marxist ideological context in which it rooted originally.

Keywords: legal culture, sociological concept of law, professional legal culture, social legal consciousness

Tisztelettel és barátsággal ajánlom ezt az irást Takács Péternek 65. születésnapja alkalmából

\section{Bevezetés}

Az alábbi tanulmány $A$ magyar jogtudat-kutatások elméleti és módszertani kérdései címmel indult kutatási program részeként született, ${ }^{2}$ amelynek megvalósítására 2020-ban az Eötvös József Kutatóközpont támogatásával, illetve az annak kebelében működő Információs Társadalom Kutatóintézettel együttműködésben kerül sor. A jogi kultúra és a társadalmi szintű jogtudat fogalmi elemzésére irányuló következő eszmefuttatás bizonyos elemeit már néhány korábbi közleményemben bemutattam, $\mathrm{s}$ amelyekre a jelen fejtegetéseimben is támaszkodni fogok. ${ }^{3}$

A jelen tanulmány célja tehát a jogi kultúra és a társadalmi szintű jogtudat fogalmi relációinak elemzése. A gondolatmenet első részében áttekintem, hogy a jogi kultúra koncepciója hogyan jelent meg a hazai jogtörténet, összehasonlító jogtudomány és a jogszociológia - közelebbről a jogtudatkutatások - terén. Majd a jogi antropológiai vizsgálódásaim során kidolgozott kultúrafogalom bemutatását követően térek rá a jogi kultúra általam javasolt fogalmának kibontására, elsőként a „kultúra” mint

2 A projekt részletes bemutatására lásd H. Szilágyi István: Kísérlet a magyar jogtudat-kutatások elméleti és módszertani kérdéseinek áttekintésére. MTA Law Working Papers, (2020), 12. 24.

3 H. Szilágyi István: A jogi antropológia fóbb irányai. Történeti és elméleti vázlat. Budapest, Osiris, 2000b; H. Szilágyi István (szerk.): Jog és antropológia. Budapest, Osiris, 2000a; H. Szilágyi István (szerk.): Társadalmi jogi kutatások. Egyetemi jegyzet. Budapest, Szent István Társulat, 2012; H. Szilágyi István: A jogtudat-kutatások elméleti problématérképe. In H. Szilágyi István (szerk.): Jogtudat-kutatások Magyarországon 1867-2017. Budapest, Pázmány Press, 2018. 97-122; H. Szilágyi István - Jankó-Badó Andrea: „Ha nem vagyunk úriemberek, azzal sincs baj..." In H. Szilágyi István (szerk.): Jogtudat-kutatások Magyarországon 1867-2017. Budapest, Pázmány Press, 2018. 323-354; H. Szilágyi István: Adalékok a jogi kultúra fogalmához. In Nagy Janka Teodóra (szerk.): A jogi kultúrtörténet és a jogi néprajz új forrásai. I. Szekszárd, Pécsi Tudományegyetem Kultúrtörténeti, Pedagógusképző és Vidékfejlesztési Kar, 2018. 109-124; H. Szilágyi István: A kutatás elméleti háttere. In H. Szilágyi István - Kelemen László: Miként vélekedünk a jogról? Szociálpszichológiai kutatás 2018. Budapest, HVG-ORAC, 2019. 14-54. 
törzsfogalom, majd a „jog” szociológiai koncepciójának felvázolásával. Annak érdekében, hogy a jogi kultúra fogalmát jobban megvilágítsam, példaként a „professzionális jogi kultúra" egy sajátos szeletének, az ügyvédség hivatási önképének egy nemrégiben végzett empirikus kutatás során készített konceptuális elemzését fogom ismertetni. Ezt követően a jogi kultúra fogalma körül az 1970-es évektől napjainkig terjedő periódusban kibontakozó nemzetközi tudományos vitákban kialakult elképzelésekre tekintettel igyekszem tisztázni a jogi kultúra és a társadalmi jogtudat fogalmi viszonyát.

\section{A „jogi kultúra” fogalmának megjelenése a hazai kutatásokban}

A „kultúra” mint tudományos fogalom a múlt század második felében, a szocializmus korszakában általában diszkreditálódott a hazai humaniórában, és különösen a politikailag amúgy is érzékeny elméleti jogtudományban. A marxizmus kierőszakolt hegemóniájának idején a „kultúra” a „gazdasági alapot visszatükröző” - ráadásul gyakran hamisan tükröző - „ideológiai felépítménnyel” volt azonos értelmű, de mindig is hordozott egy gyanúsan „polgári” konnotációt. E periódusban így alighanem a kultúra fogalmát gyakrabban használták a biológia, az orvostudomány vagy az agrártudományok művelése során, mint a társadalomtudományokban.

Ezért - jóllehet a nemzetközi kutatásokban már jóval korábban mutatkoztak azok a törekvések, amelyek a jogot kulturális jelenségként igyekeztek értelmezni ${ }^{4}$ - jogi gondolkodásunk horizontján csupán az 1990-es években jelent meg a jogi kultúra fogalma. Elsőként a jogtörténetben - illetve az annak kebelében formálódó „jogi kultúrtörténet" kutatási területén ${ }^{5}$-, majd az összehasonlító jogtudományban. ${ }^{6} \mathrm{~A}$ jelen fejtegetések keretei között természetesen nem áll módomban részletes eszmetörténeti képet festeni e törekvésekről, így csak egy-egy fogalmi meghatározási kísérletet emelnék ki az alábbiakban, amelyek a későbbi fejtegetések kiindulópontjait képezhetik.

Érdemes idéznünk mindjárt Kajtár István tömör meghatározását, amely a jogi kultúrtörténet kutatási tárgyainak felsorolására koncentrál:

„A jogi kultúrtörténet [...] kiterjed többek között tárgyaknak, épületeknek, jelképeknek, képeknek, jeleknek, processzusoknak, ceremóniáknak, rítusoknak

$4 \quad$ Erről lásd Fekete Balázs: A kortárs jogi kultúra fogalmának eredete. Lawrence M. Friedman a jogi kultúráról. In H. Szilágyi István: Jogtudat-kutatások Magyarországon 1867-2017. 2018. 123-144; H. Szilágyi (2000b): i. m. 11-99; H. Szilágyi (2000a): i. m. 3-26.

5 A jogi kultúrtörténet meghatározó kutatóinak munkáiból lásd Mezey Barna: Szimbólumok, jelképek, igazságügyi épületek. In Kengyel Miklós (szerk.): Perkultúra: Bírák ügyvédek, ügyfelek a nyolcvanas évek végén. Pécs, Pro Pannónia, 1993. 7-13; Mezey Barna (szerk.): Jogi kultúrák, processzusok, rituálék és szimbólumok. Budapest, Gondolat, 2006; Kajtár István: Egy hatalmi jelkép kultúrtörténete: A sas. JURA, 1. (1994), 4. 11-17; Kajtár István: Jogi stílusunk kultúrtörténeti gyökereiről. In Hamza Gábor - Kajtár István - Zlinszky János (szerk.): Tanulmányok Benedek Ferenc tiszteletére. Pécs, JPTE JÁK, 1996. 124-132; Kajtár István: Bevezetés a jogi kultúrtörténetbe. Budapest-Pécs, Dialóg Campus, 2004.

6 Lásd például Varga Csaba „összehasonlító jogi kultúrák” projektjét. Vö. Varga Csaba (szerk.): Összehasonlító jogi kultúrák. Budapest, Osiris, 2000. 
jogtörténeti vizsgálatára, elemezi előbbiekkel összefüggésben (és önmagában) a szövegeket."

E definícióból, amely tulajdonképpen a jogi kultúra elemeinek felsorolását adja, arra következtethetünk, hogy e megközelítés mögött a kultúra tág értelemben vett felfogása áll, hiszen meglehetősen különböző természetű dolgokat enumerál: jelek, szimbólumok, szövegek egyrészt - amelyek kifejezetten szellemi tartalmakra utalnak -, másrészt tárgyak, épületek - a fizikai valóság darabjai -, harmadrészt eljárások, rítusok, amelyek emberi cselekvésekre utalnak.

Varga Csaba az „összehasonlító jogi kultúrák” kutatási projektjének keretében született szöveggyűjtemény előszavában más utat követ. A jogi kultúra elemeinek számbavétele, vagy valamiféle definícióba sủrített meghatározása helyett inkább annak általános jellegvonásait igyekszik kiemelni bevezető tanulmányában. ${ }^{8}$ Ilyenként emeli ki a jogi kultúrák folyamatosságát és változékonyságát, történeti meghatározottságát, a nyelvi kreativitás jelentőségét a változás és fenntartás folyamatában. Mindehhez még hozzáteszi a kultúra arculatát adó értékrendek, ethoszok, valamint a jogászi gondolkodásmód tanulmányozásának fontosságát.

Ami a jogszociológiát illeti, bár a jogi kultúra fogalma már az 1980-as években felbukkant Kulcsár Kálmán ${ }^{9}$ és Sajó András műveiben, a fogalom kibontására, ${ }^{10}$ illetve az elemzésekben való alkalmazására nem került sor a rendszerváltás előtti peridódusban. Sajó találóan jegyezi meg, hogy a „szocialista jogirodalom bizonyos idegenkedést mutatott a jog »kultúrjelenségkénti« megközelítése iránt, részben nyilván visszahatásként a neokantiánus és neohegeliánus (Radbruch, Kohler) megközelítésekre, illetve általában a kultúra felsőbbségi implikációi miatt”. ${ }^{11}$ Ez a minket érintő, az 1960-as évek közepétől kezdődő jogtudatkutatások vonatkozásában azt jelentette, ${ }^{12}$ hogy - a „szocialista jogtudomány" sajátos fogalomrendszeréhez igazodva - a jogi kultúra helyébe a „társadalmi szintű jogtudat” vagy „társadalmi jogtudat” koncepciója került. ${ }^{13}$ Mivel a „szocialista jogtudomány” fogalmai és szemléleti perspektívája többé-kevésbé reflektálatlanul tovább éltek a múlt század utolsó évtizedében, ezért azok az ezredfordulót követően is jelen vannak a hazai jogszociológiában. A fogalomhasználat - és a ve-

7 Kajtár István: Jogi kultúrtörténeti szövegek a tradíció és a modern határán. In Mezey Barna - Nagy Janka Teodóra (szerk.): Jogi néprajz - jogi kultúrtörténet. Budapest, ELTE Eötvös, 2009. 47.

8 Varga Csaba: Jogi kultúrák - összehasonlító megvilágításban. In Varga (2000): i. m. IX-XVIII.

9 Kulcsár Kálmán: Társadalom, gazdaság, jog. Budapest, Közgazdasági és Jogi Könyvkiadó, 1982. 126.

10 Sajó a jogi kultúra fogalmának szentelt kétoldalas jegyzetében elemzéseit összegezve a következő meghatározást adja: „Jogi kultúrán mi egy sajátos, a formális jogintézmények müködéséhez kapcsolódó, azokat feltételező kultúrát értünk.” [Kiemelés az eredetiben.] Sajó András: Látszat és valóság a jogban. Budapest, Közgazdasági és Jogi Könyvkiadó, 1986. 345.

11 Sajó (1986): i. m. 345.

12 Fekete Balázs - H. Szilágyi István: Jogtudat-kutatások a szocialista Magyarországon. In H. Szilágyi István: Jogtudat-kutatások Magyarországon 1867-2017. Budapest, Pázmány Press, 2018. 19-62; Gajduschek György: Empirikus jogtudat-kutatás Magyarországon 1990 után. In H. Szilágyi (2018): i. m. 63-94.

13 Vö. Sajó (1986): i. m. 344. 
lejáró szemlélet - kritikai vizsgálata csupán az elmúlt évtizedben kezdődött meg, ${ }^{14}$ párhuzamosan a jog kulturális jelenségként való felfogása iránti érdeklődés növekedésével. Tegyük hozzá, hogy a részben marxista (neomarxista) ihletettségü, és a jogszociológiai kutatásokra napjainkig nagy hatású Critical Legal Studies mozgalom képviselői szintén napjainkig használják a ,jogtudat” (legal consciousness) kifejezést a csoport, osztály vagy társadalmi szintü „ideológiai” képződményekre (és az egyéni tudati jelenségekre) is.

Kritikai elemzésünk kiindulópontjául a jogtudat egyéni és társadalmi szintjének megkülönböztetése kínálkozott. Ezt a distinkciót az 1970-es években dolgozta ki a hazai jogszociológia, ${ }^{15}$ amely részben magyarázza, hogy az egyénivel szembeállított „társadalmi” bizonyos fokig meghatározatlan maradt. Ennek oka az volt, hogy bár a kutatók számára világos volt, hogy a társadalmi rétegződésnek nagy jelentősége van a szocialista társadalom viszonyai között is, de a politikai ideológia szintjén vágyott "Osztálynélküli társadalom” képzete, valamint a hagyományos közösségek lerombolásának, illetve a spontán csoportképződés akadályozásának tényleges politikai gyakorlata egyaránt abba az irányba hatott, hogy a „társadalmi” szint fogalmát az „össztársadalmi", vagyis az állami szinttel azonosítsák. Az egyéni és társadalmi szint elválasztása tehát egyúttal kimondatlanul azt a képet sugallta, hogy az egyén minden további közvetítő csoport közbejötte nélkül, közvetlenül kapcsolódik a társadalmat képviselő államhoz. ${ }^{16}$ Az egyénnek a társadalomhoz mint legátfogóbb csoporthoz való kapcsolata efféle felfogásának túlzottan leegyszerüsítő voltával valójában már akkor tisztában voltak a kutatók.

E meglátás vezetett el az egyén és a - szokásosan az állami intézményrendszerrel vagy kormányzattal azonosított - társadalmi szint közötti közvetítő szerkezetek elemzéséhez, vagyis a társadalmi szerkezet, a szocietális és a professzionális csoportok társadalmi jogtudatot differenciáló hatásának vizsgálatához, amelyek közül szempontunkból kiemelkedő jelentősége volt a jogászi professziónak. ${ }^{17}$

A jogtudat társadalmi szintjével kapcsolatban viszont még egy további nehézség is adódott. Látnunk kell, hogy a jogtudat társadalmi szinten másképpen kapcsolódik a (politikai) közösséget mint egészet képviselő intézményi réteghez, mint az egyéni jogtudat az egyénhez mint társadalmi és pszichofizikai realitáshoz. Szemben az egyénnek a saját jogtudatához való kapcsolatával, az állam egyáltalán nem kizárólagos hordozója és alakítója a társadalmi jogtudatnak. Míg az egyén viselkedéséből elvileg rekonstruálható az egyén jogtudata, addig az állami szervek „tevékenységéből” nem következtethetünk a társadalom jogtudatára minden vonatkozásban, mivel

14 Lásd H. Szilágyi István: A marxista társadalomtudományi fogalmak használhatatlansága. In Pénzes Ferenc - Rácz Sándor - Tóth-Matolcsi László (szerk.): A szabadság felelőssége. Írások a 65 éves Dénes Iván Zoltán tiszteletére. Debrecen, DUP, 2011. 324-337; H. Szilágyi István: A jogtudat-kutatások problématérképe. In H. Szilágyi (2018): i. m. 97-122.

15 Lásd Sajó András: Jogi nézetek az egyéni tudatban. Állam-és Jogtudomány, (1976), 3.

16 E problémáról lásd szintén H. Szilágyi (2011): i. m.

17 Vö. H. Szilágyi (2018): i. m. 
ez utóbbi sokkal tágabb jelenségkört foglal magában és sokkal komplexebb összefüggésben van az államként azonosított intézményi réteggel.

A legkézenfekvőbb érvnek amellett a megfontolás mellett - amelynek azonban messze ható módszertani implikációi vannak -, hogy a „társadalmi jogtudat” helyébe a jogszociológiai vizsgálatok szempontjából világosabb és éppen ezért operacionalizálhatóbb „jogi kultúra” fogalmát állítsuk, egyébként az tűnt, hogy a társadalmi jogtudat egy „kollektív személyiség” létét feltételezi (a marxi „osztálytudat” mintájára), ami viszont az empirikus vizsgálódások szempontjából nem értelmezhető. Lélektanilag szabatos értelemben tudata csupán az egyénnek van, és a számára külsődleges, társadalmilag adott, többé-kevésbé objektivált formában jelentkező „gondolati”, „eszmei” (érzékileg közvetlenül nem megragadható) jelenségek a kultúra szférájába tartoznak.

A jogi kultúra vizsgálódásaink kiindulópontját jelentő, munkahipotézisnek tekinthető definícióját a következőképpen adtuk meg: a jogi kultúra a joggal kapcsolatos értékek, normák, szimbólumok, narratívák és a társadalmi gyakorlatok sajátos mintázatainak összessége. A jogi kultúra közvetlenül kapcsolódik a legitimitás fogalma mentén a politikai kultúrához ${ }^{18}$ és egyébként is éles határok nélkül, szervesen illeszkedik a kultúra egészének szövetébe. E meghatározás persze feltételezi a „jog” valamely kultúrakutatásban használható fogalmának kidolgozását, amire az alábbiakban még visszatérünk.

A jogi kultúrán belül el kell választanunk továbbá a „laikus” és a „professzionális” jogi kultúra terrénumát. Ez utóbbi gondozása a jogászi hivatásrend társadalmi funkciója - és tulajdonképpen monopóliuma -, vagyis a jogi kultúra normatív rétegének „karbantartása”, illetve az ahhoz kapcsolódó doktrinális-dogmatikai réteg kidolgozása. Nyilvánvaló, hogy a jogi kultúra egészének formálódása szempontjából az utóbbinak van döntő jelentősége - miként az is, hogy az előbbi, a jog müködéséről a laikusokban kialakult kép, jelentősen eltérhet a jogászok által „befelé” (a jogászság felé) és „kifelé” (a társadalom egésze felé) sugározni kívánt képtől.

A jogi kultúra fogalmának pontosabb meghatározása azonban megkívánja a „kultúra” mint törzsfogalom és a „jog” mint megkülönböztető jellegvonás kifejtését.

\section{Egy kísérlet a kultúra fogalmi megragadására}

A kultúra általunk javasolt koncepciója ${ }^{19}$ mögött álló emberkép alapja az, hogy az ember kultúrával, illetve kultúrában élő lény, aki mindenestül - egész lényével - a kultú-

18 Erről lásd Martin Krygier: The Rule of Law. Legality, Teleology, Sociology. In Gianluigi Palombella - Neil Walker (szerk.): Relocating the Rule of Law. Oxford, Hart Publishing, 2009. 45-69.

19 H. Szilágyi István: Ember, társadalom, kultúra - alapfogalmak. In H. Szilágyi István - Cserne Péter - Fekete Balázs: Társadalmi-jogi kutatások. Egyetemi jegyzet. Budapest, Szent István Társulat, 2012. 26-43. A következő vázlat alapvetően a kulturális antropológiai kutatásaimon alapul, és a kidolgozásához felhasznált fontosabb szakirodalom: Ruth Fulton Benedict: Patterns of Culture. Boston, Houghton Mifflin, 1962; Bibó István: Az európai társadalomfejlődés értelme. In Válogatott tanulmányok, III. köt. Budapest, Magvető, 1986. 5-124; Clifford Geertz: Az értelmezés hatalma. [Ford: Andor Eszter et al.] Budapest, Osiris, 2001; Alfred Louis Kroeber: A kultúra fogalma 
rába ágyazottan létezik. Tehát a természeti és társadalmi környezetéhez való viszonyát nem pusztán szükségletei és biológiai adottságai határozzák meg, hanem viselkedésére legalább ilyen fontos hatással vannak a világról kialakított eszméi.

Mielőtt a kultúra további konceptuális analízisébe bocsátkoznánk, érdemes rögzítenünk néhány általános jellegvonását, amelyet a következőkben mindig beleértünk a fogalomba.

Elöször is, a kultúra fogalma mindig valamilyen közösségre utal. A kultúra közösségi alkotás, amelybe az ember beleszületik, már készen várja az egyént. Senki nem alkothat egymaga kultúrát. Ebből következik - s ezzel kiegészíthetjük egyúttal a fenti emberképet -, hogy az ember természete szerint társas lény.

Másodszor, hogy a kultúra az egyén számára ugyanakkor nem abban az értelemben adott, mint a biológiai adottságai. Az egyén élete folyamán cselekedeteivel fenntartja és alakítja a kultúrát. Az egyes ember maga is részese a kultúra alakításának, s nem csupán passzív alanya vagy hordozója annak.

Végezetül, a kultúra - miként az azt hordozó és alakító emberek is - időben létezik, méghozzá, amíg egyáltalán létezik, addig folyamatosan létezik. Bármennyire is reméli egy-egy új generáció, soha nem lehet benne „tiszta lapot” kezdeni. ${ }^{20} \mathrm{~A}$ kultúra tehát történeti jelenség, hagyomány, amely a múltból érkezik, s az ember élete folyamán hordozza súlyát (vagy „édes terhét”), közben hozzáteszi a magáét és át is adja utódainak.

Elemzésünk következő lépéseként a kultúra fogalmát a „minta” fogalmára vezetjük vissza. Bár a minta fogalmát is széles körben és sokféle értelemben használják, mégis található néhány közös elem ezekben. Az egyik ilyen a szabályosság mozzanata: a minta az ismétlődés képzetét kelti, ami a legkülönbözőbb dimenziókban jelentkezhet térben és időben. Ha a minta valamiképpen összefüggésbe hozható az idővel, akkor a szabályos ismétlődés, a tartósság képzetéhez társul. A minta fogalma ugyanakkor a „formára” is utal, amely elválasztható a megmintázott dologtól, a minta hordozójától.

a tudományban. In Paul Bohannan - Marc Glazer (szerk.): Mérföldkövek a kulturális antropológiában. Budapest, Panem - Macgrow-Hill, 1997. 159-187; Claude Lévi-Strauss: Strukturális antropológia I-II. [Ford.: Saly Noémi, Szántó Diana] Budapest, Osiris, 2001; Edmund Leach: Szociálantropológia. [Ford. Pusztai Anikó - Sajó Tamás] Budapest, Osiris, 1996; Robert H. Lowie: A kultúra meghatározói. In Paul Bohannan - Marc Glazer (szerk.): Mérföldkövek a kulturális antropológiában. Budapest, Panem - Macgrow-Hill, 1997. 190-206; Victor Turner: A rituális folyamat. Budapest, Osiris, 2002; Eric R. Wolf: Európa és a történelem nélküli népek. Budapest, Akadémiai - Osiris - Századvég, 1995; Leslie A. White: The Science of Culture. New York, Farrar Straus \& Giroux, 1969.

20 „[A] fejlődés teremtményei vagyunk a kozmosz, az ökológia és a kultúra skáláján. Ugyanakkor teremtők is ez utóbbi kettőn. Sehol nem található azonban egy olyan töréspont, amely feljogosítana bennünket arra, hogy figyelmen kívül hagyjuk azt, ami az elött történt. A történelem olyan, mint egy beszélő tapéta: ha egy darabját kivágjuk, s szekrénybe tesszük, akkor nem fogjuk megérteni az üzenetét annak, ami a falon maradt" - írja erről Ian G. Simmons, a neves történeti ökológus. Ian G. Simmons: Environmental History. A Concise Introduction. Oxford - Cambridge MS, WileyBlackwell, 1993. 188. 
Természetesen a minta fogalma a legkülönbözőbb szempontok szerint tovább bontható (például tartalom, szerkezet, a megmintázott dolog természete szerint), s így a legkülönbözőbb mintákról beszélhetünk. Számunkra ez csupán annyiban fontos, hogy a minta fogalmát összefüggésbe hozhatjuk az emberi viselkedéssel is, amenynyiben feltételezzük, hogy abban bizonyos tartós szabályosságok figyelhetők meg. Így jutunk el a „kulturális minta” fogalmához, amely egy adott közösségben az emberi viselkedés olyan formáit és szabályosságait jelöli, amelyek nem a biológiai adottságokból (öröklött tulajdonságok) származtathatók.

Itt meg kell jegyeznünk, hogy az emberi viselkedés biológiai és kulturális mintái nem függetlenek egymástól. Bizonyos körülmények között a szerzett (tanult) minták örökletessé válhatnak, továbbá vitatott, hogy egyes rendszeresen bekövetkező viselkedési formák mennyiben tudhatók be a biológiai adottságoknak, és mennyiben a kulturális mintáknak.

A minta általános koncepciójához tartozik még a deskriptív (leíró) és a preskriptív (előíró) minták megkülönböztetése. Az előbbi esetében egy már létező dologban felfedezhető mintára gondolunk - „valaminek” a mintája (például egy fosszília mészkőben maradt lenyomata). A preskriptív minta ellenben valamilyen ezután megformálandó, kialakítandó dolog mintája - „valami számára” készült minta (például egy ház tervrajza). Ez a megkülönböztetés értelmezhető a kulturális mintákra is, s nem kis jelentősége van a szociológiai vizsgálódások szempontjából: egy dolog az, ahogy az emberek valóságban cselekednek a társadalmi gyakorlatban - ez az, amit a szociológia leír (szociológiai minták) -, és más dolog az, hogy mit gondolnak az emberek arról, hogy miként kellene cselekedniük - vagyis az elvárt, elöírt cselekvés mintái. A kulturális minták e két fajtája természetesen szintén nem független egymástól, és adott esetben nem is olyan egyszerü megmondani, hogy egy minta leíró vagy elöíró jellegüe. Például, ha egy már meglévő házról készítünk egy műszaki rajzot, az annak a leíró mintáját adja, de ha az alapján új házakat építünk, akkor az előíró mintává változik. A kulturális minták leíró vagy elöíró jellege tehát valójában a társadalmi gyakorlatban való alkalmazásuktól, használatuktól függ.

Összefoglalva az eddigieket, a kultúra fogalmát általánosságban tehát úgy határozhatjuk meg, mint az adott közösségre jellemző kulturális minták összeségét, amelyek a társadalom tagjai - csoportjai, vagy akár a különböző társadalmak közötti, sőt, ideérthetjük a természeti környezet és a társadalom - közötti interakciókat formálják.

A kultúra azonban nem valamiféle amorf masszája a kulturális mintáknak, hanem belső rendezettsége, tagoltsága van. E belső struktúra egyik aspektusát az adja, hogy a minták a társadalmi élet milyen jelenségeire vonatkoznak. Ez alapján beszélhetünk szexuális kultúráról, lakáskultúráról vagy éppen politikai vagy jogi kultúráról. Másfelől a kultúra igazodik társadalmi szerkezethez is. Az összetett, modern társadalmakban így a társadalmi rétegződéshez, valamint a szocietális (család, rokonság, lakóhelyi közösség, baráti kör) és a munkamegosztás funkcionális tagozódását követő professzionális (foglalkozási, hivatási) csoportok szerkezetéhez. 
A kulturális minták rétegeinek ez a viszonylagos elkülönülése és összekapcsolódása nem valami mechanikus összmüködés, hanem a kultúra belső dinamikájának a következménye. A kultúra e belső, a társadalmi valóságtól részben független, de azzal kölcsönhatásban álló önmozgásának legfőbb hajtóereje a nyelvben és a szimbólumokban rejlő kreativitás.

A hagyományos felfogás szerint a nyelv a kultúra „kötőszövete”, hiszen a kulturális minták legfőbb hordozó közege, a társadalom tagjai közötti kommunikáció alapvető formája. A nyelv azonban - mint azt a „nyelvfilozófiai fordulatot” követően a bölcseletben, illetve a múlt század második felében intézményesülő szociolingvisztika újabb kutatásai nyomán egyre nyilvánvalóbbá vált - nemcsak hordozza és összekapcsolja a kulturális minták rétegeit, hanem maga is közrejátszik azok teremtésében. A nyelv tehát nem csupán a kommunikáció passzív, semleges eszköze, hanem a kultúra konstitutív eleme. $^{21}$

A nyelvi jelek maguk is többjelentésủek, s tulajdonképpen a nyelvet tekinthetjük a szimbólumok egy sajátos rendszerének. A szimbólumok többjelentésủ jelek, amelyeket hordozójuk természete szerint is csoportosíthatunk (nyelvi, képi, tárgyi stb.). A társadalmi cselekvések - Weber meghatározását kölcsönözve: az olyan emberi cselekvések, amelyek a cselekvő szándékolt értelme szerint mások cselekvéseire vonatkoznak, vagy menetükben ezekhez igazodnak ${ }^{22}$ - általában is szimbolikus jellegűek, és értelmük éppen a kultúra kontextusában fejthető meg. Bizonyos szimbolikus cselekvések, a rítusok esetében pedig éppen a formalizált cselekvési sor önmagában vett értelmetlensége teszi lehetővé, hogy az abban részt vevőket annak ellenére is öszszekapcsolják, hogy azok egyébként eltérő értékek vagy ütköző érdekek, elképzelések által motiváltak. A szimbólumok sajátos funkciókat látnak el a kommunikációban. Egyrészt helyettesítenek bizonyos dolgokat - mint minden jel -, másrészt integrálják a közösséget, mert csak az adott közösség tagjai fogják ismerni a szimbólumhoz kapcsolódó gazdag jelentéstartalmat. Nagyon fontos jellemzője még a szimbólumoknak, hogy nemcsak a kognitív szférában müködnek, hanem képesek sajátos érzelmek felkeltésére is, ezzel is növelve a közösség kohézióját.

A kulturális minták tehát nem csak úgy közömbösen lebegnek egymás mellett, hanem áttekinthetetlenül bonyolult és sokoldalú kapcsolatok füzik őket össze.

21 A nyelvi kreativitás kérdéséhez lásd John Lionel Austin: Tetten ért szavak. Budapest, Akadémiai, 1990; Philippe Breton: A manipulált beszéd. Budapest, Helikon, 2000; Noam Chomsky: Mondattani szerkezetek. Nyelv és elme. Budapest, Osiris, 2003; Dell H. Hymes: A nyelv és társadalom kölcsönhatásának vizsgálata. [Ford.: Csepeli György.] In Pléh Csaba - Síklaki István - Terestyéni Tamás: Nyelv - kommunikáció - cselekvés. Budapest, Osiris, 2001. 458-495; Charles Sanders Peirce: Collected Papers of Charles Sanders Peirce. Cambridge, MS, Harvard University Press, 1974; Ferdinand de Saussure: Bevezetés az általános nyelvészetbe. Budapest, Gondolat, 1967; John R. Searle: Közvetett beszédaktusok. Budapest, Gondolat, 2009; Michael Silverstein: Metapragmatic Discourse and Metapragmatic Functions. In John A. Lucy (szerk.): Reflexive Language. Reported Speech and Metapragmatics. Cambridge, Cambridge University Press, 1993. 33-58; Ronald Wardhaugh: Szociolingvisztika. Budapest, Osiris, 2005.

22 Vö. Max Weber: Gazdaság és társadalom. A megértö szociológia alapvonalai. I. köt. [Ford.: Erdélyi Ágnes]. Budapest, Közgazdasági és Jogi Könyvkiadó, 1992. 38. 
$\mathrm{Az}$ „áttekinthetetlen” jelző nem túlzás: minden kultúra egy egész világ. A kulturális antropológiában rendkívül nagy jelentősége volt annak a felismerésnek, hogy a kultúrát önálló egészként, sajátos belső szerkezettel és arculattal rendelkező entitásként kell felfognunk. ${ }^{23} \mathrm{~A}$ kultúrának a társadalmi, fizikai valóságtól való relatív függetlenségének pontosan ez a belső rendezettség és önmozgás az alapja.

\section{A jogi kultúra koncepciója}

Mint azt fentebb már jeleztük, a jogi kultúra fogalmi megragadásának előfeltétele a „kultúra” törzsfogalmának kifejtése mellett a „jog” valamilyen, az empirikus kultúrakutatások számára használható szociológiai meghatározása. A jogszociológiában megjelenő, Roger Cotterrell által elkülönített három jellegzetes fogalomalkotási stratégia - „jogi monizmus”, „jogi pluralizmus” és a „közvetíto elméletek” - közül leginkább a „közvetítő elméletek” tűntek számunkra gyümölcsözőnek..$^{24}$ Az idetartozó koncepciók közös vonása, hogy a jogot szélesebben határozzák meg a „jogászok jogánál" vagy az állami jognál, és a jogászok jogra vonatkozó gyakorlati meghatározásait is inadekvátnak tekintik szociológiailag, mégis a jog fogalmát úgy korlátozzák, hogy kitüntetett szerepet és világos elsőbbséget tulajdonítanak az állami jognak napjaink modern társadalmaiban. Az általunk javasolt megoldás lényege ${ }^{25}$ hogy a jog törzsfogalmaként a társadalmi müködés funkcionális elemzéséből nyert „társadalmi kontroll” fogalmát állítjuk, míg megkülönböztető jegyeként a kultúra fenti fogalmi elemzésére építő konceptuális elemet adjuk.

A jog a társadalmi kontroll egy sajátos formája, azon kulturális minták összessége, amelyek érvényesülését az állam biztosítja.

A definíció első fele két dologról tájékoztat minket. Az egyik, hogy a társadalmi kontroll fogalma szélesebb a jognál, hiszen a jog annak csupán egyik - hangsúlyozzuk: történetileg adott - formája.

23 Jól érzékelteti a kultúra belső dinamikáját és autonómiáját Ruth Fulton Benedict egyik idevonatkozó példája: „A kultúrák integrációja a legkevésbé sem misztikus. Egy művészeti stílus ugyanilyen folyamat eredményeként jön létre és él tovább. A gótikus építészet, ami kezdetben nem egyéb a magasság és a fény iránti vonzalomnál, bizonyos, technikájából fakadó, ízlésbeli zsinórmérték müködésének eredményeként a XIII. század egyedi és egységes művészeti stílusává változott. A nem hozzá illő elemeket kivetette magából, másokat céljainak megfelelően módosított, és ízlésével egyező új elemeket talált fel. Amikor történetileg írjuk le a folyamatot, elkerülhetetlenül megszemélyesített kifejezési formákkal élünk, mintha bizony választásokról és célokról lett volna szó ennek a művészeti formának a kialakulása során. Ez azonban csak nyelvi kifejezőeszközeink fogyatékosságainak tudható be. Nem volt tudatos döntés, nem volt cél. Az, ami eleinte nem volt több helyi formák és technikák fokozottabb kedvelésénél, egyre erőteljesebb kifejezést nyert, egyre világosabban meghatározott szabvány szerint integrálódott, és végül a gótikus művészetben tetőzött." Ruth Fulton Benedict: A kultúra integrációja. In Paul Bohannan - Mark Glazer: Mérföldkövek a kulturális antropológiában. Budapest, Panem - Macgrow-Hill, 1997. 255.

24 Vö. Roger Cotterrell: A jog szociológiai fogalma. In Szabadfalvi József (szerk.): Mai angol-amerikai jogelméleti törekvések. Miskolc, Bíbor, 1996. 57-74.

25 Erről lásd bővebben H. Szilágyi István: Jog és társadalmi kontroll. In H. Szilágyi (2012): i. m. 70-91. 
„A társadalmi kontroll a társadalmi élet normatív aspektusa. Meghatározza és válaszol a deviáns magatartásokra elöírva, hogy minek kell lennie: mi a jó és mi a rossz, mi a sértés, az abnormalitás, a szakadás [...]. A jog társadalmi kontroll [...], de ugyanúgy az az etikett, az erkölcs, a bürokrácia, a mentális betegségek kezelése. Miként a jog az állam társadalmi kontrollja az állampolgárok között, ugyanúgy egy törzs tagjainak is megvan a maguk társadalmi kontrollja, ahogy egy család tagjainak, vagy ahogyan egy munkahelynek, felekezetnek, klikknek és játéknak is." ${ }^{26}$

A második dolog, amire a meghatározás első fele figyelmeztet bennünket az az, hogy kutatásunk területét nem korlátozhatjuk a jogra. A jog érvényesülésének és hatékonyságának problémáit csak a társadalmi kontroll többi formájára tekintettel elemezhetjük.

Tekintettel arra, hogy a „kulturális minták” mibenlétét már tárgyaltuk a fentiekben, így a meghatározásunk második fordulata kapcsán két dolog szorul további tisztázásra: az egyik az „állam” fogalma, a másik pedig, hogy mit jelent az, hogy „az állam biztosítja" bizonyos kulturális minták érvényesülését.

Az „állam” fogalmát itt a „modern nemzetállam” történeti típusára korlátozzuk, hozzátéve ehhez, hogy szociológiai szempontból nagyon lényeges azt szem előtt tartanunk, hogy az állam egy rendkívül bonyolult és tagolt intézményi szerkezet.

Ami az állami tevékenység és a jognak tekintett kulturális minták közötti viszonyt illeti, itt szintén egy sokrétű kapcsolatrendszert kell feltételeznünk. Ez magában foglalja az egészen közvetlen hatásoktól kezdve - mikor az állam alkotja és közvetlenül kikényszeríti a szabályokat (például „behajtja” az adót) - egészen az olyan esetekig, mikor a kapcsolat, mondhatni „laza”. Például mikor egy vitás polgári jogi ügyletnél a felek a várható bírósági döntésre tekintettel kötnek egyezséget, vagy mikor az állam meghatározza az oktatásban kötelező tantervet vagy az érettségi követelményeit. Ez utóbbi esetekben világos, hogy az állam nem is alkotja a kulturális mintákat, és nem is kényszeríti ki azok érvényesülését, mégis hatással van az események menetére.

Az állami tevékenység és bizonyos kulturális minták érvényesülése közötti kapcsolat közvetettségének feltételezése, valamint hogy a jog törzsfogalmaként a társadalmi kontrollt jelöltük meg, lehetővé teszi, hogy a jogi pluralizmus szemléletéből adódó megfontolásokat is figyelembe vegyünk. A jogi jelenségek vizsgálatakor tehát nem hagyhatók figyelmen kívül a társadalmi szerkezet különböző szegmenseiben létrejövő erőterek, félautonóm társadalmi mezők hatásai sem.

Előttünk áll tehát a szociológiai jogfogalom, amelyre tekintettel most már kibonthatjuk a jogi kultúra fogalmát. Ebben az értelmezésben ez utóbbi azoknak a kulturális mintáknak a szövedéke, amelyek tárgya a „jog” - az állam közbejöttével, az állam működése folytán érvényesülő kulturális minták -, s amelyek a „jogot” beágyazzák a kultúra tágabb közegébe.

26 Donald Black: The Behavior of Law. New York, Academic Press, 1976. 15. 


\section{A jogi kultúra aspektusai: laikus és professzionális jogi kultúra}

Annak érdekében, hogy a jogi kultúra fogalmát jobban megvilágítsuk, érdemes példaként bemutatnunk a „professzionális jogi kultúra” egy sajátos szeletének, az ügyvédség hivatási önképének egy nemrégiben végzett empirikus kutatás során készített konceptuális elemzését. ${ }^{27}$

Kiindulópontunk tehát, hogy az ügyvédség önképéről folyó beszélyt a kultúráról, s azon belül a jogi kultúráról folyó diskurzusba kell helyeznünk, és ebben a viszonylatban az ügyvédség önképét a - „laikus”, tehát nem jogász állampolgárok jogi kultúrájától elválasztott vagy azzal szembeállított - „professzionális jogi kultúra” egyik elemeként fogjuk fel. A hivatás önképe azonban maga is szellemi tartalmak, elemek együtteseként értelmezhető: értékek, normák, leíró jellegü kulturális minták, narratívák, szimbólumok és a hivatás képviselőinek magatartásáról leolvasható minták szövevényeként.

Az ügyvédi hivatás önképében megjelenő jellegzetes értékek - szakmai felkészültség (magas szintű jogismeret), igazságérzet, elfogulatlanság, az ügyfél érdekeinek feltétlen tisztelete stb. - egyúttal a jogászi hivatás általánosabb értékeihez is tartoznak, és beágyazódnak a politikai kultúra még átfogóbb értékeibe, mint amilyenek a szabadság, egyenlőség vagy a társadalmi szolidaritás értékei.

Az önképnek a társadalmi cselekvések szintjéhez eggyel közelebb eső rétege a hivatás szabályainak rétege, amelyek egy része „írott”, jogi vagy jogi jellegű szabály, mint esetünkben például az ügyvédekről szóló 1998. évi XI. törvény vagy az ügyvédi kamarák etikai kódexei. Mindezek mellett természetesen léteznek íratlan szabályai - például kollegiális vagy a laikusokkal való érintkezés „udvariassági” szabályai - is a hivatásnak, amelyek szintén a hivatási önkép részét képezik.

A leíró jellegü kulturális minták elsősorban nem azt mondják meg, hogy mit kell tenniük az adott helyzetben lévő cselevőknek, hanem kijelölik a cselekvők pozícióját és kompetenciáját - tudósítanak arról, hogy egy adott társadalmi csoportnak mi a helye, cselekvési köre a társadalomban vagy közelebbről a jog világában. Esetünkben például a polgári perrendtartásról szóló törvény pervezetésre vonatkozó szabályai, amelyek címzettjei elsősorban a bírák, egyúttal kijelölik az ügyvédek pozícióját és lehetőségeit a pervitel menetének befolyásolására vonatkozóan. ${ }^{28}$

Az értékeket, az előíró és leíró kulturális minták a fentiekben analitikusan elválasztott rétegeit a narratívák, esetünkben az ügyvédek által ismert és elbeszélt történetek szövik össze, egyúttal megteremtve - Robert Cover megfogalmazásával élve - azt a normatív univerzumot, amelyekben ezek jelentést nyernek. ${ }^{29}$ Minden hivatásnak vannak „nagy történetei”, mint például a magyar ügyvédség története, amelyet egyéb-

27 H. Szilágyi - Jankó-Badó (2018): i. m.

28 A normatív (preskriptív) és a leíró (deskriptív) jellegű kulturális minták fogalmáról lásd H. Szilágyi (2012): i. m.

29 Vö. Nagy Tamás: Narratív tematika a kortárs amerikai jogelméletben. In Nagy Tamás: Josef K. nyomában. Jogról és irodalomról. Máriabesnyő-Gödöllő, Attraktor, 2010. 125-160. 
ként a jogtörténet diszciplínája hivatott kidolgozni, és az egyetemi képzés során előadni, „elmesélni” a jövendő ügyvédek számára. E nagy narratívák a hivatás mint korporatív csoport történetének fontosabb fordulópontjai, kiemelkedő alakjai köré fonódnak, amelyek az egész hivatási csoport identitásának alapját képezik. Ezekre a nagy narratívákra függeszkednek a lokális, „,árosi legendák” és a személyes történetek szövevényei, amelyek ezer szállal kapcsolódnak a kultúra más területeihez. ${ }^{30}$

Az önképet kifejező szimbólumok itt megint csak nem a maguk fizikai valóságában értendők - luxusautó, drága karóra, rizsporos paróka, talár, „nagyon okos” telefon, csúcsminőségủ laptop stb. -, hanem mint sokjelentésủ jelek. A szimbólumok egyszerre képesek jelezni a hivatáshoz való tartozás tényét, s egyúttal komplex érzelmeket és tudattartalmakat mozgósítani a kívülállókban. Az ügyvédek esetében fokozott jelentősége van például a státuszszimbólumoknak, amelyek nemcsak a középosztályhoz való tartozásukat jelzik, hanem egyúttal a sikeresség képzetét is keltik az ügyfelekben (mint például a luxusautó vagy a márkás karóra), ${ }^{31}$ míg más szimbólumok (mint például egykor az ügyvédi táska) ${ }^{32}$ kifejezetten a hivatáshoz való tartozást jelzik. A hivatásba való belépéshez, illetve az odatartozáshoz bizonyos rítusok, szertatások is kapcsolódnak, mint amilyen a doktori eskü, vagy a kollégák közötti érintkezés udvariassági formái.

Szólnunk kell még a hivatás gyakorlóinak viselkedéséből leolvasható minták rétegeiről, amelyek a tacit tudáshoz tartoznak, s amelyeket a hivatásba belépők a kollégák tevékenységének megfigyelésével, „ellesésével” ismernek meg. Ezek a hivatás fortélyai, ${ }^{33}$ trükkjei, ${ }^{34}$ amelyek csak a gyakorlatban sajátíthatók el, s amelyek gyakran jelentősen eltérnek a hivatás manifeszt önképének idealizált értékeitől és szabályaitól.

Fontos látnunk, hogy annak ellenére, hogy a hivatási önkép formálásának alapvető tendenciája az értelmi egységre, belső koherenciára való törekvés, az önkép fent említett elemei és rétegei között mindig támadnak ellentmondások, belső feszültségek. Feltételezhetően minél koherensebb és világosabb az önkép, annál jobban képes biztosítani a hivatás gyakorlói közötti kohéziót, s jelentősen hozzájárulhat a hivatás érdekérvényesítő képességéhez. S fordítva, minél ellentmondásosabb, töredezettebb,

30 Így lesz például az amerikai televíziós sorozat főszereplője - a becsületes, az ártatlan védencek igazáért végsőkig küzdő ügyvéd, Petrocelli - után (gúnyosan) elnevezve a cigányok jogait védő egri ügyvéd Putricellinek. Vö. H. Szilágyi István: Nincs kegyelem - senkinek. In Fekete Balázs - H. Szilágyi István - Nagy Tamás (szerk.): Iustitia mesél. Tanulmányok a „jog és irodalom” köréböl. Budapest, Szent István Társulat, 2013. 89-112.

31 Az ügyvédek által státuszszimbólumként birtokolt javak részletes elemzésére lásd Utasi Ágnes (szerk.): Ügyvédek a gyorsuló időben (1998-2015). Szeged, Belvedere Meridionale, 2016.

32 „Régen, még egyetemista koromban is, olyan volt az ügyvédi táska, mint az orvostáska, ilyen hoszszúkás, és mindenki úgy készítette el a beadványát, hogy ketté volt hajtva az A/4-es papír, ez volt a szokásos méretezés. Ilyenek voltak az aktaborítók is, minden erre volt szabva." Középkorú, vidéki ügyvéddel készített interjú. Utasi (2016): i. m. 258.

33 Mint például az ügyfelekkel vagy a hivatás más csoportjainak tagjaival való hatékony tárgyalás stratégiája. Vö. Középkorú, nagyvárosi városi ügyvédnővel készített interjú. Utasi (2016): i. m. 243.

34 Mint például a hat példányban készülő szerződés aláirásakor egy-két példány becsúsztatása, amelyeken a vételárként kisebb összeget tűntetnek fel, mint ami a tényleges megállapodásban szerepel. 
homályosabb a professzió önképe, annál kevésbé képes integrálni tagjait, $\mathrm{s}$ annál védtelenebb a külső hatásokkal szemben. A szilárd és világos hivatási önképnek a professzió társadalmi helyzete alakulása szempontjából vett szerepe azonban mindig empirikus kérdés: a túlságosan erős korporatív szellem is válhat a társadalmi változásokra való adekvát reagálás akadályává.

Végezetül ki kell emelnünk a hivatás önképe és a laikusok által a hivatásról kialakított kép közötti viszony dinamikus jellegét. A kettő kölcsönösen alakítja egymást, egy olyan játékteret létrehozva, amely nélkülözhetetlen a társadalmi változásokhoz való alkalmazkodáshoz, vagy éppen a változások indukálásához.

Mi az, ami az eddigiekből fontos számunkra a továbblépéshez? Először is, hogy a laikus jogi kultúra szerkezete hasonló a professzionáliséhoz, csupán a normatív-dogmatikai rétege sokkal vékonyabb, és még inkább töredezett, logikai ellentmondásokkal terhes. E két jellemző - vagyis a jogismeret viszonylag alacsony szintjét, ${ }^{35}$ valamint a logikai ellentmondások jelenlétét a jogról alkotott laikus nézetekben ${ }^{36}$ - fennállását megerősítették a magyar lakosság körében végzett legfrissebb kutatások is. E különbségek azonban fokozati jellegủek - még ha nagyon lényegesek is -, és nem érintik a jogi kultúra e két aspektusának alapvető azonosságát az összetevők, a szerkezet és az elemeket összekötő finomszövet tekintetében. Ebből következik, hogy a laikus jogi kultúra leírása és megértése szempontjából is nagyon fontosak a jogról szóló, vagy a joggal kapcsolatos történetek ${ }^{37} \mathrm{E}$ narratívák, amelyek nem csupán a jogi kultúra elemeit - az értékeket, normákat, szimbólumokat és a társadalmi gyakorlatban kikristályosodó cselekvési, gondolkodási mintákat - kapcsolják és rendezik össze, hanem egyúttal a jogi kultúrát is beleszövik a kultúra egészébe.

\section{Jogi kultúra versus társadalmi szintü jogtudat}

Fejtegetésünk e pontján érdemes még egyszer visszatérnünk a jogi kultúra és a társadalmi szintű jogtudat fogalmának vizsgálatához. A két fogalom előzetes elemzésekor az utóbbi elvetését javasoltuk, és főként a társadalmi szintű jogtudat koncepciójával szemben felvetődő érveket vettük számba. Így az egyéni és a társadalmi szintű jogtudat elválasztásának nehézségére utaltunk, mikor hangsúlyoztuk, hogy a jogtudat társadalmi szinten másképpen kapcsolódik a (politikai) közösséget mint egészet képviselő intézményi réteghez, mint az egyéni jogtudat az egyénhez mint társadalmi és pszichofizikai realitáshoz. Szemben az egyénnek a saját jogtudatához való kapcso-

35 A jogismeret vonatkozásában lásd Gajduschek György - Fekete Balázs: A magyar lakosság jogismerete az elmúlt közel fél évszázadban. In H. Szilágyi (2018): i. m. 173-220.

36 Berkics Mihály: Laikusok és jogászok nézetei a jogról. Rendszer és jogrendszer percepciói Magyarországon. In Hunyady György - Berkics Mihály: A jog szociálpszichológiája: A hiányzó láncszem. Budapest, ELTE Eötvös, 2015. 141-160; 337-364.

37 Ebből a szempontból különösen fontosak a jogi néprajz újabb fejleményei közül Lancerdorfer Zsuzsanna kutatásai. Lásd például Lanczendorfer Zsuzsanna: Gyilkosságból népköltészet. Helyi népballadák a jogtörténet szolgálatában. In Fekete Balázs et al. (szerk.): Iustitia körülnéz. Budapest, Szent István Társulat, 2017. 117-129. 
latával, az állam egyáltalán nem kizárólagos hordozója és alakítója a társadalmi jogtudatnak. Míg az egyén viselkedéséből elvileg rekonstruálható az egyén jogtudata, addig az állami szervek „tevékenységéből” nem következtethetünk a társadalom jogtudatára minden vonatkozásban, mivel ez utóbbi sokkal tágabb jelenségkört foglal magában és sokkal komplexebb összefüggésben van az államként azonosított intézményi réteggel.

Másfelől arra is felhívtuk a figyelmet, hogy a társadalmi szintű jogtudat fogalma mélyen beágyazott a marxizmus eszmei hagyományába, s így fenn áll a veszélye annak, hogy reflektálatlan használata során felidézi az „osztály-tudat” mintájára felfogott, valamilyen "kollektív személyiség” képzetét, ami viszont az empirikus vizsgálódások szempontjából nem értelmezhető. Lélektanilag szabatos értelemben tudata csupán az egyénnek van, és a számára külsődleges, társadalmilag adott, többé-kevésbé objektivált formában jelentkező „gondolati”, „eszmei” (érzékileg közvetlenül nem megragadható) jelenségek a kultúra szférájába tartoznak.

Erre tekintettel a jogi kultúra elemeinek felsorolásakor is kihagytuk az attitűdök és azok társadalmi szinten kialakuló mintázatainak említését, hiszen ezek hordozói valójában a társadalom tagjai mint egyének, tehát inkább az egyéni jogtudat jelenségéhez kapcsolódnak.

Vizsgáljuk meg azonban most a jogi kultúra koncepciójának empirikus kutatásokban való használhatóságára vonatkozó kételyeket is, amihez kiindulópontként kínálkozik Lawrence Friedman közel fél évszázada megjelent műve ${ }^{38}$ nyomán kialakult tudományos vita áttekintése. ${ }^{39}$ Friedman jogrendszerről írt munkájában a jogi kultúra fogalmának többféle meghatározását (a) adta, különféle fogalmi elemeket kiemelve. A kötet első, teoretikus bevezetőül szolgáló fejezetében például a jogi kultúrát az általában vett kultúra részének tekinti: „[A]z általános kultúra azon részei - szokások, vélekedések, a cselekvés és a gondolkodás módjai -, amelyek a társadalmi erőket a jog felé vagy a jogtól eltérő irányba hajlítják." ${ }^{40}$ A jogi kultúráról szóló fejezetben pedig a jogi kultúra fogalma „a jogról szóló ismeretekre, illetve az arra vonatkozó attitűdökre és viselkedési mintákra utal". ${ }^{41}$ Egy későbbi művében a fogalmi elemek hasonló, némileg bővített változatával találkozhatunk: „eszmék, attitűdök, elvárások és vélemények, melyeket az emberek egy bizonyos társadalomban a jogra vonatkozóan

38 Lawrence M. Friedman: The Legal System. A Social Science Perspective. New York, Russel Sage Foundation, 1975.

39 A vita bizonyos aspektusainak összefoglalására lásd David Nelken: Disclosing/Invoking Legal Culture: An Introduction. Social \& Legal Studies, 4. (1995), 4. 435-452; Susan S. Silbey: Legal Culture and Legal Consciousness. International Encyclopedia of the Social and Behavioral Sciences. Elsevier, 2001. 8624-8626; Marina Kurkchiyan: Russian Legal Culture: An Analysis of Adaptive Response to an Institutional Transplant. Law E Social Inquiry, 34. (2009), 2. 337-338; Fekete (2018): i. m.

40 Friedman (1975): i. m. 15.

41 Friedman (1975): i. m. 193. 
tartanak". ${ }^{42}$ Más esetekben pedig az említett elemek egyfajta „aggregátumaként” írja le a jogi kultúrát. ${ }^{43}$

Másfelől Friedman hangsúlyozza, hogy a jogi kultúra fogalmát különböző szinteken lehet értelmezni (b). Beszélhetünk egy nemzet jogi kultúrájáról, de ugyanígy egy vidék, egy társadalmi csoport esetében is értelmezhetjük ezt. ${ }^{44} \mathrm{~A}$ skála másik irányában mozogva pedig nagyobb történeti periódusokra - például a „modernitás jogi kultúrája” 45 -, illetve nagyobb földrajzi egységekre - „nyugati jogi kultúra"46 - jellemzésére alkalmazható fogalomként.

Harmadrészt, Friedman a jogi kultúra jelenségén belül elkülöníti a „külső” és „belső” jogi kultúrát (c). ${ }^{47} \mathrm{Az}$ előbbi a laikus állampolgárok, míg az utóbbi „az adott társadalom valamilyen speciális jogi feladatot ellátó tagjainak"48 jogi kultúráját jelöli, $\mathrm{s}$ aminek megkülönböztetett jelentőséget tulajdonít a jogrendszer működése szempontjából. ${ }^{49}$

Számos ponton egyetérthetünk a friedmani koncepció legalaposabb bírálója, Roger Cotterrell meglátásaival. Cotterrell rámutat arra, hogy a jogi kultúra Friedman által adott meghatározásának (ad a) fogalmi homályossága egyfelől lehetővé teszi, hogy átfogó, egyfajta reziduális kategóriaként alkalmazzák - például a jogösszehasonlítás terén a jogrendszerek csoportosítása kapcsán -, de az empirikus kutatásokban már jóval csekélyebb magyarázó ereje van. Különösen mivel a felsorolt fogalmi elemek meglehetősen heterogén természete nem könnyíti meg a jogi kultúrának az aktuális társadalmi folyamatokkal való összekapcsolását. ${ }^{50}$ Robert L. Kidder e problémát még élesebben fogalmazza, mikor arról a tapasztalatáról számol be, hogy az egyesült államokbeli amish közösségekben és a Japánban folytatott terepmunkája során a megfigyelt csoportok jogi kultúrájáról alkotott előzetes kép mintegy „eltűnt” az empirikus anyag értelmezésekor. ${ }^{51}$

Susan S. Silbey e kérdés kapcsán jelzi, hogy az elméleti bizonytalanságok egy része abból fakad, hogy a jogi kultúra fogalmának kétféle jelentése van, amelyek az egyes elméletekben összekeveredhetnek. A jogi kultúra ugyanis egyrészt használható az értelemteljes társadalmi cselekvések szemiotikai aspektusainak szociológiai elem-

42 Lawrence M. Friedman: The Republic of Choice: Law, Authority, and Culture. Cambridge MS, Harvard University Press, 1990. 213.

43 Friedman (1990): i. m. 212, 213.

44 Friedman (1975): i. m. 199.

45 Lawrence M. Friedman: Is There a Modern Legal Culture? Ratio Juris, 7. (1994). 117-131.

46 Friedman (1990): i. m. 198-199.

47 Vö. Friedman (1975): i. m. 223. Erről lásd még Lawrence M. Friedman: Law and Society: An Introduction. Englewood Cliffs NY, Prentice Hall, 1977. 76. Friedman (1990): i. m. 4.

48 Friedman (1990): i. m. 223.

49 Friedman (1990): i. m. 194.

50 Roger Cotterrell: Law, Culture \& Society. Burlington, Ashgate, 2006. 83-88.

51 Robert L. Kidder: Exploring Legal Culture in Law-Avoidance Societies. In June Starr - Mark Goodale (szerk.): Practicing Ethnography in Law. New Dialogues, Enduring Methods. New York, Palgrave, 2002. 98-99. 
zési eszközeként, ${ }^{52}$ másrészt azonban egy adott csoport vagy társadalom cselekvési és gondolkodási mintáiból képződő konkrét világ leírásának eszközéül is. Silbey szerint a probléma egyik lehetséges megoldása, amely felé egyébként a közelmúltban kialakuló kutatási irányok fogalomhasználata is halad, hogy a makroszintű elméleti és összehasonlító kutatásokban a jogi kultúra fogalmát (mint szemiotikai analitikai eszközt) használjuk, míg a mikroszintü kutatásokban - különösen amikor a vizsgálat tárgya az, hogy az egyének hogyan értelmezik és mozgósítják a jogi jelentéseket és jeleket - a jogi kultúra helyett inkább a jogtudat fogalmát alkalmazzuk..$^{53}$

Ezzel szemben David Nelken azt az álláspontot fogalmazza meg, hogy az európai összehasonlító jogi kutatásokban ${ }^{54}$ már kialakult a jogi kultúra többrétegü (multi layered) felfogása, amely magában foglalja a jogi normák, a jogi intézmények jellegzetes formáinak és „infrastruktúrájának”, a jogot létrehozó, használó vagy nem használó viselkedések, valamint a jogászok és a laikusok jogtudatának vizsgálatát. Erre tekintettel úgy véli, hogy a jogi kultúra fogalma megtartható és az aktuális kutatásokra tekintettel pontosítható, kifejthető koncepció. Nelken egyúttal elveti Cotterrell javaslatát, hogy a fogalmilag tisztázatlan jogi kultúra helyébe a ,jogi ideológia” koncepcióját kellene állítani, amely jobban kifejezi a jognak a politikai diskurzushoz kötöttségét. Nelken hangsúlyozza, hogy ez a fogalomcsere aligha lenne gyümölcsöző, hiszen az ideológia koncepciója legalább annyira vitatott és többértelmű, mint a kultúráé, és mélyen beágyazott a (marxista) kritikai elméletekbe, amelyek szemlélete és célkitűzései nem feltétlenül egyeznek a szociológiai kutatásokéval. ${ }^{55}$

Visszatérve Cotterrell kritikai eszmefuttatásához, a szerző szerint Friedman két irányban is túlfeszíti a jogi kultúra fogalmát ( $\mathrm{ad}$ b). Egyrészt térben és időben hatalmas kiterjedésű egységek - „modernitás”, „nyugati jogi kultúra” - jellemzésére is alkalmasnak tartja. Másrészt viszont - főként későbbi műveiben - Friedman a jogi pluralizmus radikális felfogásához látszik csatlakozni, mikor azt hangsúlyozza, hogy a jogi kultúra fogalma értelmezhető minden „állam alatti” társadalmi egységre - helyi, vallási, etnikai stb. csoportokra - is, s így a jogi kultúra mint a „kultúrák szédítő parádéja" ${ }^{6}$ tủnik fel. Kevés útmutatást ad azonban arra nézve, hogy e sokféle kulturális „aggregátum” hogyan képes nagyobb egységekbe integrálódni. ${ }^{57}$

52 Erről lásd David M. Engel - Barbara Yngvesson: Mapping Difficult Terrain: „Legal Culture,” „Legal Consciousness" and Other Hazards for the Intrepid Explorer. Law E Policy, 6. (1984), 3. 299-307.

53 Vö. Silbey (2001): i. m. 8624.

54 Itt Nelken elsősorban Erhardt Blankenburg kutatásaira utal. Lásd Erhard Blankenburg: The Infrastucture for Avoiding Civil Litigation. Comparing Cultures of Legal Behaviour in the Netherlands and West Germany. Law E Society Review, 28. (1994), 4. 789-809; Erhard Blankenburg: Civil Litigation Rates as Indicators for Legal Cultures. In David Nelken (szerk.): Comparing Legal Cultures. Aldershot, Dartmouth, 1997. 41-68.

55 Nelken(1995): i. m. 438-439, 446.

56 Friedman (1990): i. m. 213.

57 Cotterrell (2006): i. m. 84. 
Valójában ezen a ponton Cotterrell a radikális jogi pluralizmus felfogásának arra a nehézségére mutat rá, amelyet Andrew Arno „jogi exkluzivizmusnak” nevezett. ${ }^{58}$ A jogi exkluzivizmusnak azt a tendenciát jelöli, amely a jogi jelenségeknek kiemelkedő, központi jelentőséget tulajdonít a többi társadalmi jelenséghez képest. Ez a radikális jogi pluralizmus esetében abban a formában jelentkezik, hogy a társadalmi kontroll valamennyi formáját jognak tekinti. ${ }^{59} \mathrm{~A}$ jog fogalmának ilyen irányú kiterjesztése viszont a koncepció megkettőződéséhez vezet: egyrészt létrejön a jog analitikai, másrészt a történeti fogalma. Ez nem csupán a jog történeti perspektívájának elvesztésével fenyeget ${ }^{60}$ hanem megnehezíti a jog és a társadalmi kontroll többi formája közötti viszony magyarázatát is.

Ami a „külső" és a „belső” jogi kultúra friedmani elválasztását illeti (ad c), Cotterrell kifejti, hogy a fogalom fentebb jelzett homályossága folytán e megkülönböztetés elveszíti szociológiai magyarázó erejének javarészét. Nem kapunk egyértelmű választ arra a kérdésre, hogy vajon miért kellene a jog múködése szempontjából fontosabbnak tartanunk a „belső” jogi kultúrát, mint a „külsőt”, s hogy a két aspektust milyen kapcsolat füzi össze. Továbbá, mivel Friedman hangsúlyozza a jogi kultúra diverzitását és pluralitását, miközben végsőleg mégiscsak egységként kezeli azt, ezért a „belső” aspektus úgy tünik fel, mint a jogi kultúra egységét képviselő aggregátum, szembe állítva a sokféleséget jelképező „külső” aspektussal. ${ }^{61}$

Mielőtt elemzésünkben tovább lépnénk, érdemes röviden összefoglalni az ismertetett diszkussziónak a jogi kultúra általunk vázolt koncepciója szempontjából levonható tanulságait, sorra véve a felmerült vitapontokat.

58 Lásd Andrew Arno: Structural Communication and Control Communication: An Interactionist Perspective on Legal and Customary Procedures for Conflict Management. American Anthropologist, 87. (1985), 1. 40-45. A jogi exkluzivizmus kérdéséhez lásd még Carol J. Greenhouse: Looking at Culture, Looking for Rules. Man, 17. (1982), 1. 53-78; H Szilágyi (2000): i. m. 109-114.

59 „A jogi antropológia [...] rendelkezett azzal az előnnyel, hogy az empirikus kutatásainak nagyobb részét olyan társadalmi csoportoknak szentelte, melyek híján vannak a specializált jogi intézményeknek és szerepeknek. Amíg azonban a legbefolyásosabb jogi antropológusok többsége szerint az informális társadalmi kontroll mechanizmusai - amilyeneket például az eszkimók körében figyeltek meg - ténylegesen a jog egy formáját képviselik [...], akkor az ilyen állítások csupán újabb bizonyítékot szolgáltatnak a jogi exkluzivizmus átható erejére. Ebben az esetben az exkluzivizmus abban a szélsőséges formában jelentkezik, hogy a feje tetejére állítja a jog társadalmi kontrollként való fogalmasítását, és a társadalmi kontroll összes formáját jogként tünteti fel. Ez olyan álláspont, mely főleg mint válasz müködik arra a fülsértő jellemzésre, hogy a törzsi társadalmak »jog nélküliek« volnának. Ez a megközelítésmód azonban nem korlátozta az antropológiai kutatások területét a kisléptékủ társadalmakban, mivel a jogként azonosított intézmények funkcionálisan beilleszkedtek a csoport társadalmi folyamatainak egészébe. A zavar ott kezdődött [...], amikor az antropológusok elkezdték saját társadalmaikat vizsgálni, és a »jog « fogalmát szokatlan és egyáltalán nem meggyőző módon használni." H Szilágyi (2000): i. m. 41.

60 Vö. Martin Chanock: Law, Custom and Social Order. The Colonial Experience in Malawi and Zambia. Cambridge, Cambridge University Press, 1985. 31-47; Laura Nader: Harmony Ideology. Justice and Control in a Zapotec Mountain Village. Stanford, Stanford University Press, 1990. 315.

61 Cotterrell (2006): i. m. 85-86. 
Az első (ad a) és alighanem legalapvetőbb megfontolás, amely a fentebb ismertetett érvek nyomán kibontakozik, hogy a jogi kultúra fogalma nem alkotható meg sem a kultúra, sem pedig a jog szociológiai fogalmának előzetes tisztázása nélkül. Ennek az elvárásnak igyekezett is eleget tenni az általunk javasolt koncepció, ami persze egyáltalán nem teszi feleslegessé a további, részletesebb kifejtést. Az a döntés, hogy a kultúra fogalmát tisztán objektivált szellemi tartalmakra - értékek, normák, szimbólumok, narratívák - korlátoztuk, a fogalomképzést abba az irányba terelte, hogy az így megadott koncepciót elsősorban az „értelemteljes társadalmi cselekvések” szemiotikai elemzésének eszközéül szolgáljon. Mi több, fejtegetésünk éppen kiemelte a kultúra (jogi kultúra) önállóságát, a tényleges társadalmi körülményektől való viszonylagos függetlenségét. Nyitva maradt azonban az a kérdés, hogy hogyan lehet az így megalkotott fogalmat az aktuális társadalmi folyamatokkal kapcsolatba hozni. Elégséges-e az értékek morális érzelmeket kiváltó hatására, vagy a szimbólumok integratív funkciójára utalnunk? Vajon aggály nélkül elhelyezhetők-e a kultúra említett fogalmi elemei közé a társadalmi gyakorlatok mintázatai, a jogra vonatkozó egyéni vélemények, attitűdök társadalmi szinten, spontán módon kialakuló mintázatai?

Ami a jogi kultúra egységét, illetve sokféleségét illeti (ad b), az általunk vázolt koncepció, bár kezelhetővé teszi a jogi kultúrának a társadalmi szerkezethez igazodó tagoltságából fakadó sokféleségét, mégis elkerüli a radikális pluralista szemlélet buktatóját azáltal, hogy a jog szociológiai fogalmát a modern nemzetállam történeti jelenségéhez köti.

Hasonlóképpen elkerüli a jogi kultúra „külső” és „belső” aspektusának elválasztása nyomán felvetődött nehézségeket ( $\mathrm{ad} \mathrm{c}$ ), mikor hangsúlyozza a „laikus” és a „profeszszionális" jogi kultúra közötti elválasztás viszonylagosságát és a két aspektus szerves kapcsolatát.

Választ keresve a vizsgálódásaink nyomán megoldatlanul maradt dilemmákra, alighanem vissza kell térnünk a kultúra attribútumainak tárgyalásához. A kultúra egyik fontos jellegvonásaként említettük, hogy az közösségi alkotás, s ebből kifolyólag tételeztük, hogy az ember társas lény. Erre tekintettel azonban figyelembe kell vennünk, hogy az egyéni psziché más törvényszerüségeknek alávetetten működik, mint a közösségi lelki jelenségek. Az előbbi a pszichológia, az utóbbi a társas lélektan terrénumára esik. Az a törekvésünk, hogy a kultúra (jogi kultúra) fogalmát megtisztítsuk a pszichológiai mozzanatoktól, alighanem védhető, azonban elhamarkodottan soroltunk minden lelki természetű jelenséget az egyéni jogtudat fogalma alá.

Figyelembe véve tehát, hogy az empirikus jogtudatkutatásokban milyen nagy jelentősége van a társadalom-lélektani aspektusnak, valamint arra, hogy az egyéni attitűdök és azoknak a társadalmi vagy csoportszintủ eloszlásai különböző módon állnak elő - az egyik az egyéni psziché, a másik a társadalom-lélektan törvényszerűségei 
szerint alakul -, ezért felvethető, hogy a jogtudat társadalmi szintű értelmezését nem kellene teljességgel elvetni. ${ }^{62}$

E fogalomalkotási stratégia jelenik meg például Kahei Rokumoto egy 2004-es munkájában vázolt elméletében, aki a jogi kultúrát (legal culture) a társadalmi szintű jogtudat (legal consciousness) részének tekinti, a jogismeret (legal knowledge) és a jogra vonatkozó attitüdök (legal attitudes), valamint a jogi érzelmek (legal sentiments) mellett. A jogi kultúra magfogalma a jogfogalom (legal conception), amely meglehetős időbeli tartósságot mutat, szemben a jogismerettel és a jogra vonatkozó beállítódásokkal, érzelmekkel, amelyek rövid időn belül is jelentősen változhatnak. ${ }^{63}$

E kérdés tisztázása azonban még további teoretikus vizsgálódásokat igényel. Tekintetbe véve az előzetes kritikai megfontolásainkat, amelyek a fogalom elvetésére vezettek, nem tűnik célravezetőnek visszahozni a „társadalmi jogtudat” fogalmát mint valamiféle reziduális kategóriát, amelybe egyszerűen besoroljuk az összes olyan társadalom-lélektani - attitüdök, vélemények, hitek, tömegérzelmek - mozzanatot, amelyek nem vonhatók aggály nélkül a jogi kultúra koncepciójába. A továbblépéshez Marc Hertogh a jogtudat fogalmával kapcsolatos két eszmefuttatását érdemes felidéznünk.

Hertogh két stratégiát különböztet meg a jogtudat koncepciójának felépítésére vonatkozóan: az amerikai és az európai felfogást. ${ }^{64} \mathrm{Az}$ előbbi Roscoe Pound munkásságára vezethető vissza, és lényege a law in books és a law in action megkülönböztetése. ${ }^{65} \mathrm{~A}$ jogszociológiai vizsgálódások célja a kettő közötti eltérés feltárása, vagyis hogy a gyakorlatban érvényesülő (hivatalos) jog hogyan, miért és milyen mértékben tér el a hivatalostól. Az erre a hagyományra épülő jogtudatkutatások központi kérdése pedig, hogy az emberek hogyan érzékelik a hivatalos jogot. A jog ebben a szemléletben független változó lesz, a jogtudat pedig a jogtól való eltérés magyarázó tényezője.

Ezzel szemben a jogtudat európai koncepcióját elsősorban Eugen Ehrlich munkássága inspirálta, ${ }^{66}$ amelynek középpontjában az „élő jog” fogalma áll. A szociológiai kutatásnak nem a hivatalos jogra, hanem a jog életének súlypontját jelentő „élő jogra" kell összpontosítania, mivel a hivatalos jogot csupán a jogviták eldöntése során alkalmazzák az állami szervek, az élő jog azonban a vita nélkül teljesedésbe menő ügyletekben érvényesül, amelyek a jogélet túlnyomó részét képezik. E szemléletből

62 Ezt a meglátást Fleck Zoltán fogalmazta meg $A$ jogi kultúra természetrajza címmel tartott tudományos szimpóziumon (a PPKE JÁK Jogbölcseleti Tanszék Jogszociológiai és a Jog és nyelv kutatócsoportjának közös rendezésében. PPKE JÁK, Budapest, 2019. május 2.).

63 Rokumoto elméletének ismertetésére lásd Masayuki Murayama: Culture, Situation and Behaviour. In Dimitri Vanorverbeke et al.: The Changing Role of Law in Japan. Cheltenham UK - Northampton MA USA, Edward Elgar, 2014. 191. Ugyancsak a jogi kultúra és a társadalmi jogtudat fogalmi összekapcsolását javasolja Marina Kurkchiyan is, aki azzal a megoldással él, hogy a jogtudat fogalmát rendeli a jogi kultúra alá, azt mint a jogi kultúra egyik elemeként meghatározva. Vö: Kurkchiyan (2009): i. m.

64 Marc Hertogh: A 'European' Concept of Legal Consciousness: Rediscovering Eugen Ehrlich. Journal of Law \& Society Review, 31. (2004), 4. 457-481.

65 Lásd Roscoe Pound: Law in Books and Law in Action. American Law Review, 44. (1910), 12.

66 Lásd Eugen Ehrlich - Nathan Isaacs: The Sociology of Law. Harvard Law Review, 36. (1920), 130; Eugen Ehrlich: Das lebende Recht der Völker der Bukowina. Recht und Wirtshaft, 1. (1912). 
a jogtudatkutatások fő kérdése ezért nem az, hogy az emberek hogyan érzékelik a hivatalos jogot, hanem hogy egyáltalán mit érzékelnek jogként. Így a jog függőváltozóvá válik e perspektívából szemlélve.

Hertogh másik gondolatmenetében különbséget tesz a jogtudatkutatások megközelítésmódja, a „kritikai” (critical) és a „szekuláris” (secular) között. ${ }^{67}$ Az előbbi szorosan kapcsolódik egyfelől a - jelentős részben neomarxista inspirációjú - Critical Legal Studies hagyományához, másfelől a jogtudat fent ismertetett amerikai felfogásához. Az 1970-es évektől az ezredfordulóig tartó három évtizedben számos jelentős kutatás született ebben a szemléletben, ${ }^{68}$ amelynek közös vonása, hogy elsősorban arra keresték a választ, hogy az emberek miért fordulnak a joghoz, dacára annak, hogy az valójában érdekeik ellen müködik, s rendre csalatkozniuk kell a jogban. A társadalmi életben a jog mindent átható jelenlétét, hegemóniáját igyekeztek kimutatni, és elsősorban a jog elfogadásának és támogatásának motívumait feltárni.

A „szekuláris” ${ }^{69}$ megközelítés - amelyet maga Hertogh is képvisel - viszont a jogtudat európai koncepciójára támaszkodva elutasítja azt, hogy a jog hegemóniáját adottnak tekintse, és elsősorban arra koncentrál, hogy az emberek miért nem követik a hivatalos jogot, és helyette milyen alternatív megoldásokat keresnek. A jog elfogadása helyett tehát a jogtól való elidegenedés, a jog elkerülésének, a joggal való szembeszegülésnek és a hivatalos jog helyett érvényesülő alternatív társadalmi kontroll formáira összpontosítja figyelmét.

Milyen következtetések adódnak számunkra a társadalmi jogtudat fogalmi megragadása szempontjából a fenti fejtegetésekből? Először is, hogy a társadalmi jogtudatot olyan jelenségként kell elképzelnünk, amely kölcsönhatásban van a jogi kultúrával. A társadalmi tudat szempontjából a jog (jogi kultúra) hol független változóként jelenik, hol pedig függő változóként. A jogi kultúra formálja a jogtudatot, de egyúttal a társadalmi jogtudat által formált is. A jogtudat Hertogh által vázolt amerikai és az európai koncepciója valójában az „érem két oldalát” jelképezi, e kölcsönhatás két relációját világítja meg.

Másfelől a társadalmi jogtudatot úgy kell felfognunk, mint ami az egyént a társadalomhoz kapcsoló strukturális elemek - szocietális és professzionális csoportok -

67 Marc Hertogh: Nobody's Law. Legal Consciousness and Legal Alienation in Everyday Life. London, Palgrave, 2018. 1-15.

68 Lásd például Marc Galanter: Why the "Haves" Come out Ahead. Speculations on the Limits of Legal Change. Law \& Society Review, 9. (1974), 1. 95-160; Marc Galanter: Justice in Many Rooms. Courts, Private Ordering, and Indigenous Law. Journal of Legal Pluralism and Uniofficial Law, 13. (1981), 19. 1-47; Sally Engle Merry: Getting Justice and Getting Even: Legal Consciousness among Working-Class Americans. Chicago, Chicago University Press, 1990; Patricia Ewick - Susan S. Silbey: The Common Place of Law. Stories from Everyday Life. Chicago, Chicago University Press, 1998; David Engel: How Does Law Matter in the Constitution of Legal Consciousness? In Bryant G. Garth - Austin Sarat: How Does Law Matter? Chicago, Northwestern University Press, 1998. 109144; Laura Beth Nielsen: Situating Legal Consciousness: Experiences and Attitudes of Ordinary Citizens about Law and Street Harassment. Law \& Society Review, 34. (2000), 4. 1055-1090.

69 A „szekuláris” elnevezés iróniája nehezen eltéveszthető, ha figyelembe vesszük a „kritikai” szemlélet híveinek marxista elkötelezettségét. 
szerint, a jogi kultúrához hasonlóan, maga is belsőleg tagolt. Korántsem bizonyos továbbá, hogy a hivatalos jog a társadalom minden szegmensében képes teljes mértékben uralni az interakciókat, ezért a jogra irányuló negatív attitüdök és érzelmek vizsgálata éppolyan fontos, mint a jog elfogadásának, támogatásának vizsgálata.

\section{7. Összegzés: egyéni jogtudat, társadalmi jogtudat, jogi kultúra}

Vizsgálódásaink kezdőpontján áttekintettük a hazai elméleti jogtudományban a jogi kultúra fogalmi megragadására tett kísérleteket, amelyek meglehetősen kifejtetlenek maradtak, részben az ismert eszmetörténeti körülmények, részben pedig az ilyen irányú teoretikus tájékozódás szerény mértékű igénye miatt.

Ezt követően elvetettük a „társadalmi jogtudat” fogalmát, tekintettel az egyéni és a társadalmi szintű jogtudat elválasztásának nehézségére, valamint, hogy a társadalmi szintű jogtudat fogalma mélyen beágyazott a marxizmus eszmei hagyományába. Így fenn áll a veszélye annak, hogy reflektálatlan használata során felidézi az „osztály-tudat” mintájára felfogott, valamilyen „kollektív személyiség” képzetét, amely viszont az empirikus vizsgálódások szempontjából nem értelmezhető. Ezért azt a megoldást választottuk, hogy a társadalmi jogtudat fogalmának helyébe a jogi kultúra koncepcióját helyezzük, és az összes lélektani jellegű mozzanatot az egyéni jogtudat fogalma alá soroljuk.

A jogi kultúra általunk javasolt koncepciójának kidolgozásához első lépésként a kultúra törzsfogalmát igyekeztünk kifejteni, majd ezt a jog szociológiai fogalmával mint megkülönböztető jeggyel egészítettük ki. Így jutottunk el a jogi kultúra egy munkahipotézisként megadott definíciójához, miszerint az nem más, mint azoknak a kulturális mintáknak a szövedéke, amelyek tárgya a „jog” - az állam közbejöttével, az állam müködése folytán érvényesülő kulturális minták -, s amelyek a „jogot” beágyazzák a kultúra tágabb közegébe.

Fejtegetésünk következő szakaszában bevezettük a „laikus” és a „professzionális” jogi kultúra megkülönböztetését, egyúttal az ügyvédek hivatási önképéről készült elemzés példáján kibontva a jogi kultúra belső szerkezetére és felépülésére vonatkozó elképzeléseinket.

Észlelve a fogalomalkotás inkonzisztenciáit és bizonyos hiányosságait, eszmefuttatásunk utolsó részében visszatértünk annak kezdőpontjához, hogy ismét mérlegeljük, vajon helyesen jártunk-e el, amikor a társadalmi jogtudat fogalmát elvetettük. Ennek érdekében kritikai vizsgálat alá vetettük a jogi kultúra általunk javasolt koncepcióját. Ehhez a Lawrence Friedman által vázolt koncepció körül a nemzetközi irodalomban kialakult vita áttekintését használtuk tájékozódási pontokat keresve. Ennek eredményeként az a megoldás kínálkozott, hogy a társadalmi jogtudat fogalmát „viszszavegyük", s azt a jogi kultúra fogalmával összekapcsolva újraértelmezzük, elszakítva azt az eredeti marxista, neomarxista hagyománytól, amelyben eredetileg gyökerezett. Az elemzés e fázisában Kahei Rokumoto és Marc Hertogh elméleti megfontolásait igyekeztünk hasznosítani. 
Melyek volnának tehát az általunk sokszorosan újrarajzolt teoretikus vázlatnak a főbb vonásai, amelyet a jogtudatkutatások elméleti kérdéseinek feltérképezéséhez készítettünk? ${ }^{70}$

Először is látnunk kell, hogy a jogtudat formálódása többszintü, többrétegű szerkezetben zajlik, amelyek folytonos kölcsönhatásban állnak egymással. Az egyéni jogtudat, amely a jogra vonatkozó ismeretek, akarati és érzelmi elemek szövedéke az individuum lélektani törvényei szerint szerveződik. Ettől csak viszonylagosan elválasztható az egyéni jogtudat megnyilvánulásait összegző társadalmi jogtudat, amely azonban a társas érintkezés sajátos belső dinamikája szerint működik. A társadalmi jogtudat viszont elválaszthatatlanul összekapcsolódik a jogi kultúrával, amely a tömegérzelmeknél, a közvéleménynél, a közhangulattól tartósabb tárgyiasult szellemi tartalmakat, formákat rögzít, de ami maga is ki van téve a változásoknak. E változásokat pedig éppen a társadalmi jogtudat változásai idézik elő, amennyiben képesek bizonyos intenzitást elérni, illetve a társadalmi szerkezetet is módosítani.

Ehhez kapcsolódik a másik fontos vonása vázlatunknak. Mind az egyéni, mind a társadalmi jogtudat, mind pedig a jogi kultúra belső tagolódásában igazodik az egyént a társadalom egészéhez kapcsoló strukturális elemek rendszeréhez, vagyis a társadalmi struktúrához. A jogtudat vizsgálata tehát elválaszthatatlan a jogi intézményrendszer, a „jogi infrastuktúra” és a társadalmi kontroll versengő formáit működtető formális vagy informális társadalmi szerveződések, erőterek vizsgálatától.

\section{Irodalomjegyzék}

Arno, Andrew: Structural Communication and Control Communication: An Interactionist Perspective on Legal and Customary Procedures for Conflict Management. American Anthropologist, 87. (1985), 1. 40-45. Online: https://doi.org/10.1525/aa.1985.87.1.02a00050

Austin, John Lionel: Tetten ért szavak. Budapest, Akadémiai, 1990.

Benedict, Ruth Fulton: Patterns of Culture. Boston, Houghton Mifflin, 1962.

Benedict, Ruth Fulton: A kultúra integrációja. In Paul Bohannan - Mark Glazer: Mérföldkövek a kulturális antropológiában. Budapest, Panem - Macgrow-Hill, 1997. 253-261.

Berkics Mihály: Laikusok és jogászok nézetei a jogról. In Hunyady György - Berkics Mihály: A jog szociálpszichológiája: A hiányzó láncszem. Budapest, ELTE Eötvös, 2015. 141-160.

Berkics Mihály: Rendszer és jogrendszer percepciói Magyarországon. In Hunyady György - Berkics Mihály: A jog szociálpszichológiája: A hiányzó láncszem. Budapest, ELTE Eötvös, 2015. 337-364.

Bibó István: Az európai társadalomfejlődés értelme. In Válogatott tanulmányok, III. köt. Budapest, Magvető, 1986. 5-124.

Black, Donald: The Behavior of Law. New York, Academic Press, 1976.

Blankenburg, Erhad: The Infrastucture for Avoiding Civil Litigation. Comparing Cultures of Legal Behaviour in the Netherlands and West Germany. Law E Society Review, 28. (1994), 4. 789809. Online: https://doi.org/10.2307/3053997

Blankenburg, Erhard: Civil Litigation Rates as Indicators for Legal Cultures. In David Nelken (szerk.): Comparing Legal Cultures. Aldershot, Dartmouth, 1997. 41-68.

70 Vö. H. Szilágyi (2018): i. m. 
Breton, Philippe: A manipulált beszéd. Budapest, Helikon, 2000.

Chanock, Martin: Law, Custom and Social Order. The Colonial Experience in Malawi and Zambia. Cambridge, Cambridge University Press, 1985.

Chomsky, Noam: Mondattani szerkezetek. Nyelv és elme. Budapest, Osiris, 2003.

Cotterrell, Roger: A jog szociológiai fogalma. In Szabadfalvi József (szerk.): Mai angol-amerikai jogelméleti törekvések. Miskolc, Bíbor, 1996. 57-74.

Cotterrell, Roger: Law, Culture E Society. Burlington, Ashgate, 2006.

Ehrlich, Eugen: Das lebende Recht der Völker der Bukowina. Recht und Wirtshaft, 1. (1912).

Ehrlich, Eugen - Nathan Isaacs: The Sociology of Law. Harvard Law Review, 36. (1920), 2. 130. Online: https://doi.org/10.2307/1329737

Engel, David M.: How Does Law Matter in the Constitution of Legal Consciousness? In Bryant G. Garth - Austin Sarat: How Does Law Matter? Chicago, Northwestern University Press, 1998. 109-144.

Engel, David M. - Barbara Yngvesson: Mapping Difficult Terrain: „Legal Culture,” „Legal Consciousness" and Other Hazards for the Intrepid Explorer. Law \& Policy, 6. (1984), 3. 299-307. Online: https://doi.org/10.1111/j.1467-9930.1984.tb00327.x

Ewick, Patricia - Susan S. Silbey: The Common Place of Law. Stories from Everyday Life. Chicago, Chicago University Press, 1998. Online: https://doi.org/10.7208/chicago/9780226212708.001.0001

Fekete Balázs: A kortárs jogi kultúra fogalmának eredete. Lawrence M. Friedman a jogi kultúráról. In H. Szilágyi István: Jogtudat-kutatások Magyarországon 1867-2017. Budapest, Pázmány Press, 2018. 123-144.

Fekete Balázs - H. Szilágyi István: Jogtudat-kutatások a szocialista Magyarországon. In H. Szilágyi István: Jogtudat-kutatások Magyarországon 1867-2017. Budapest, Pázmány Press, 2018. 19-62.

Friedman, Lawrence M.: The Legal System. A Social Science Perspective. New York, Russel Sage Foundation, 1975.

Friedman, Lawrence M.: Law and Society: An Introduction. Englewood Cliffs NY, Prentice Hall, 1977.

Friedman, Lawrence M.: The Republic of Choice: Law, Authority, and Culture. Cambridge MS, Harvard University Press, 1990.

Friedman, Lawrence M.: Is There a Modern Legal Culture? Ratio Juris, 7. (1994), 117-131. Online: https://doi.org/10.1111/j.1467-9337.1994.tb00172.x

Gajduschek György: Empirikus jogtudat-kutatás Magyarországon 1990 után. In H. Szilágyi István: Jogtudat-kutatások Magyarországon 1867-2017. Budapest, Pázmány Press, 2018. 63-94.

Gajduschek György - Fekete Balázs: A magyar lakosság jogismerete az elmúlt közel fél évszázadban. In H. Szilágyi István: Jogtudat-kutatások Magyarországon 1867-2017. Budapest, Pázmány Press, 2018. 173-220.

Galanter, Marc: Why the "Haves" Come out Ahead. Speculations on the Limits of Legal Change. Law E Society Review, 9. (1974), 1. 95-160. Online: https://doi.org/10.2307/3053023

Galanter, Marc: Justice in Many Rooms. Courts, Private Ordering, and Indigenous Law. Journal of Legal Pluralism and Uniofficial Law, 13. (1981), 19. 1-47. Online: https://doi.org/10.1080/0732 9113.1981.10756257

Geertz, Clifford: Az értelmezés hatalma. [Ford: Andor Eszter et al.] Budapest, Osiris, 2001.

Greenhouse, Carol J.: Looking at Culture, Looking for Rules. Man, 17. (1982), 1. 58-73. Online: https://doi.org/10.2307/2802101 
Hertogh, Marc: A 'European' Concept of Legal Consciousness: Rediscovering Eugen Ehrlich. Journal of Law E Society Review, 31. (2004), 4. 457-481. Online: https://doi.org/10.1111/j.14676478.2004.00299.x

Hertogh, Marc: Nobody's Law. Legal Consciousness and Legal Alienation in Everyday Life. London, Palgrave, 2018.

H. Szilágyi István (szerk.): Jog és antropológia. Budapest, Osiris, 2000a.

H. Szilágyi István: A jogi antropológia fóbb irányai. Történeti és elméleti vázlat. Budapest, Osiris, 2000b.

H. Szilágyi István: A marxista társadalomtudományi fogalmak használhatatlansága. In Pénzes Ferenc Rácz Sándor - Tóth-Matolcsi László (szerk.): A szabadság felelössége. Írások a 65 éves Dénes Iván Zoltán tiszteletére. Debrecen, DUP, 2011.324-337.

H. Szilágyi István - Cserne Péter - Fekete Balázs: Társadalmi-jogi kutatások. Egyetemi jegyzet. Budapest, Szent István Társulat, 2012.

H. Szilágyi István: Nincs kegyelem - senkinek. In Fekete Balázs - H. Szilágyi István - Nagy Tamás (szerk.): Iustitia mesél. Tanulmányok a „jog és irodalom” köréből. Budapest, Szent István Társulat 2013. 89-112.

H. Szilágyi István: Adalékok a jogi kultúra fogalmához. In Nagy Janka Teodóra (szerk.): A jogi kultúrtörténet és a jogi néprajz új forrásai. I. Szekszárd, Pécsi Tudományegyetem Kultúrtörténeti, Pedagógusképző és Vidékfejlesztési Kar, 2018. 109-124.

H. Szilágyi István: A jogtudat-kutatások elméleti problématérképe. In H. Szilágyi István (szerk.): Jogtudat-kutatások Magyarországon 1867-2017. Budapest, Pázmány Press, 2018. 97-122.

H. Szilágyi István: A kutatás elméleti háttere. In H. Szilágyi István - Kelemen László: Miként vélekedünk a jogról? Szociálpszichológiai kutatás 2018. Budapest, HVG-ORAC, 2019. 14-54.

H. Szilágyi István: Kísérlet a magyar jogtudat-kutatások elméleti és módszertani kérdéseinek áttekintésére. MTA Law Working Papers, (2020), 12. 1-26. Online: https://jog.tk.mta.hu/mtalwp/ kiserlet-a-magyar-jogtudat-kutatasok-elmeleti-es-modszertani-kerdeseinek-attekintesere

H. Szilágyi István - Jankó-Badó Andrea: „Ha nem vagyunk úriemberek, azzal sincs baj ...” In H. Szilágyi István (szerk.): Jogtudat-kutatások Magyarországon 1867-2017. Budapest, Pázmány Press, 2018. 323-354.

Hymes, Dell H.: A nyelv és társadalom kölcsönhatásának vizsgálata. [Ford.: Csepeli György.] In Pléh Csaba - Síklaki István -Terestyéni Tamás: Nyelv - kommunikáció - cselekvés. Budapest, Osiris, 2001. 458-495.

Kajtár István: Egy hatalmi jelkép kultúrtörténete: A sas. JURA, 1. (1994), 4. 11-17.

Kajtár István: Jogi stílusunk kultúrtörténeti gyökereiről. In Hamza Gábor - Kajtár István - Zlinszky János (szerk.): Tanulmányok Benedek Ferenc tiszteletére. Pécs, JPTE JÁK, 1996. 124-132.

Kajtár István: Bevezetés a jogi kultúrtörténetbe. Budapest-Pécs, Dialóg Campus, 2004.

Kajtár István: Jogi kultúrtörténeti szövegek a tradíció és a modern határán. In Mezey Barna - Nagy Janka Teodóra (szerk.): Jogi néprajz - jogi kultúrtörténet. Budapest, ELTE Eötvös, 2009. 47-62.

Kidder, Robert L.: Exploring Legal Culture in Law-Avoidance Societies. In June Starr - Mark Goodale (szerk.): Practicing Ethnography in Law. New Dialogues, Enduring Methods. New York, Palgrave, 2002. 87-107. Online: https://doi.org/10.1007/978-1-137-06573-5_6

Kroeber, Alfred Louis: A kultúra fogalma a tudományban. In Paul Bohannan - Marc Glazer (szerk.): Mérföldkövek a kulturális antropológiában. Budapest, Panem - Macgrow-Hill, 1997. 159-187.

Krygier, Martin: The Rule of Law. Legality, Teleology, Sociology. In Gianluigi Palombella - Neil Walker (szerk.): Relocating the Rule of Law. Oxford, Hart Publishing, 2009. 45-69. Online: https://doi.org/10.5040/9781472564634.ch-003 
Kulcsár Kálmán: Társadalom, gazdaság, jog. Budapest, Közgazdasági és Jogi Könyvkiadó, 1982.

Kurkchiyan, Marina: Russian Legal Culture: An Analysis of Adaptive Response to an Institutional Transplant. Law E Social Inquiry, 34. (2009), 2. 337-364. Online: https://doi.org/10.1111/ j.1747-4469.2009.01149.x

Lanczendorfer Zsuzsanna: Gyilkosságból népköltészet. Helyi népballadák a jogtörténet szolgálatában. In Fekete Balázs - H. Szilágyi István - Kiss Anna - Ződi Zsolt (szerk.): Iustitia körülnéz. Budapest, Szent István Társulat, 2017. 117-129.

Leach, Edmund: Szociálantropológia. [Ford. Pusztai Anikó - Sajó Tamás] Budapest, Osiris, 1996.

Lévi-Strauss, Claude: Strukturális antropológia I-II. [Ford.: Saly Noémi - Szántó Diana] Budapest, Osiris, 2001.

Lowie, Robert H.: A kultúra meghatározói. In Paul Bohannan - Marc Glazer (szerk.): Mérföldkövek a kulturális antropológiában. Budapest, Panem - Macgrow-Hill, 1997. 190-206.

Merry, Sally Engle: Getting Justice and Getting Even: Legal Consciousness among Working-Class Americans. Chicago, Chicago University Press, 1990.

Mezey Barna: Szimbólumok, jelképek, igazságügyi épületek. In Kengyel Miklós (szerk.): Perkultúra: Bírák ügyvédek, ügyfelek a nyolcvanas évek végén. Pécs, Pro Pannónia, 1993. 7-13.

Mezey Barna (szerk.): Jogi kultúrák, processzusok, rituálék és szimbólumok. Budapest, Gondolat, 2006.

Murayama, Masayuki: Culture, Situation and Behaviour. In Dimitri Vanorverbeke - Jaroen Maesschalk - David Nelken - Stephan Parmentier: The Changing Role of Law in Japan. Cheltenem UK - Northampton MA USA, Edward Elgar, 2014. 189-205. Online: https://doi. org/10.4337/9781783475650.00021

Nader, Laura: Harmony Ideology. Justice and Control in a Zapotec Mountain Village. Stanford, Stanford University Press, 1990.

Nagy Tamás: Narratív tematika a kortárs amerikai jogelméletben. In Nagy Tamás: Josef K. nyomában. Jogról és irodalomról. Máriabesnyő-Gödöllö, Attraktor, 2010. 125-160.

Nelken, David: Disclosing/Invoking Legal Culture: An Introduction. Social \& Legal Studies, 4. (1995), 4. 435-452. Online: https://doi.org/10.1177/096466399500400401

Nielsen, Laura Beth: Situating Legal Consciousness: Experiences and Attitudes of Ordinary Citizens about Law and Street Harassment. Law E Society Review, 34. (2000), 4. 1055-1090. Online: https://doi.org/10.2307/3115131

Peirce, Charles Sanders: Collected Papers of Charles Sanders Peirce. Cambridge, MS, Harvard University Press, 1974.

Pound, Roscoe: Law in Books and Law in Action. American Law Review, 44. (1910), 12.

Sajó András: Jogi nézetek az egyéni tudatban. Állam-és Jogtudomány, (1976), 3.

Sajó András: Látszat és valóság a jogban. Budapest, Közgazdasági és Jogi Könyvkiadó, 1986.

Saussure, Ferdinand de: Bevezetés az általános nyelvészetbe. Budapest, Gondolat, 1967.

Searle, John R.: Közvetett beszédaktusok. Budapest, Gondolat, 2009.

Silverstein, Michael: Metapragmatic Discourse and Metapragmatic Functions. In John A. Lucy (szerk.): Reflexive Language. Reported Speech and Metapragmatics. Cambridge, Cambridge University Press, 1993. 33-58. Online: https://doi.org/10.1017/CBO9780511621031.004

Silbey, Susan S.: Legal Culture and Legal Consciousness. International Encyclopedia of the Social and Behavioral Sciences. Elsevier, 2001. 8623-8629. Online: https://doi.org/10.1016/B0-08043076-7/02913-2

Simmons, Ian G.: Environmental History. A Concise Introduction. Oxford - Cambridge MS, WileyBlackwell, 1993. 
Jogi kultúra vagy társadalmi jogtudat?

Turner, Victor: A rituális folyamat. Budapest, Osiris, 2002.

Utasi Ágnes (szerk.): Ügyvédek a gyorsuló időben (1998-2015). Szeged, Belvedere Meridionale, 2016. Online: https://doi.org/10.14232/belvbook.2016.58526

Varga Csaba (szerk.): Összehasonlító jogi kultúrák. Budapest, Osiris, 2000.

Wardhaugh, Ronald: Szociolingvisztika. Budapest, Osiris, 2005.

Weber, Max: Gazdaság és társadalom. A megértő szociológia alapvonalai. I. [Ford.: Erdélyi Ágnes]. Budapest, Közgazdasági és Jogi Könyvkiadó, 1992.

White, Leslie A.: The Science of Culture. New York, Farrar Straus \& Giroux, 1969.

Wolf, Eric R.: Európa és a történelem nélküli népek. Budapest, Akadémiai - Osiris - Századvég, 1995. 